\title{
BIOLOGICAL PROCESSES IN THE WATER COLUMN OF THE SOUTH ATLANTIC BIGHT: ZOOPLANKTON RESPONSES
}

\begin{abstract}
A PROGRESS REPORT SUBMITTED TO
U.S. DEPARTMENT OF ENERGY
\end{abstract}

GRANT DE-FG09-85ER60354

JUNE 1989 TO JUNE 1990

\author{
BY \\ SKIDAWAY INSTITUTE OF OCEANOGRAPHY \\ POST OFFICE BOX 13687 \\ SAVANNAH, GEORGIA 31416
}

GUSTAV-ADOLF PAFFENHÖFER

7 FEBRUARY 1990

\section{MASTER}

DISTRIBUTION OF THIS DOCUMENT IS UNLIMITED 


\section{TABLE OF CONTENTS}

Section

$\underline{\text { Page }}$

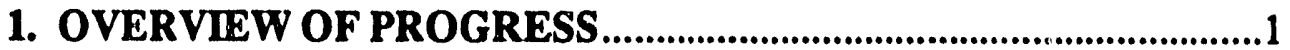

1.1 Fall Removal Experinent 1987 (FLEX) .......................................1

Introduction ...................................................................................................

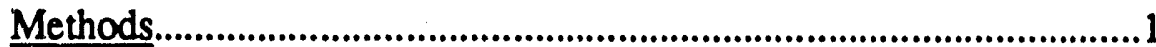

Results and Discussion ..................................................................1

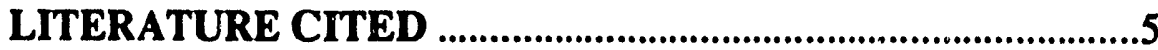

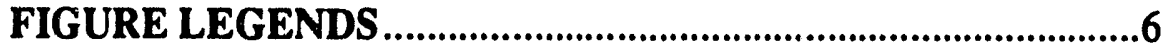

1.2 Manuscript Published During the Past Year..................................7

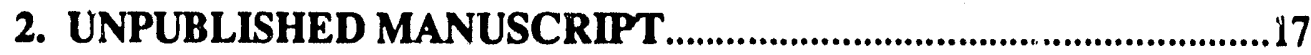

Paffenhöfer, G.-A. and K.D. Lewis. Perceptive performance and feeding behavior of calanoid copepods. Journal of Plankton

Research (in review)<smiles>[Mg][Mg][Ca][Ca]</smiles>

\section{DISCLAIMER}

This report was prepared as an account of work sponsored by an agency of the Urited States Government. Neither the United States Government nor any agency thereof, nor any of their bility for the accuracy, comply, express or implied, or assumes any legal liability or responsiprocess disclosed, or represents that it usefulness of any information, apparatus, product, or ence herein to any specific commercits use would not infringe privately owned rights. Refermanufacturer, or otherwise does not necesarily process, or service by trade name, trademark, mendation, or favoring by the United States constitute of imply its endorsement, recom. and opinions of authors expressed herein Government or any agency thereof. The views United States Government or any agency thereof. 


\section{OVERVIEW OF PROGRESS}

\subsection{Fall Removal Experiment 1987 (FLEX).}

\section{Introduction}

The goal of FLEX was to determine the processes affecting the displacement and fate of low-salinity coastal water and of biological material therein during fall when winds are mainly south-to westward (Weber and Blanton, 1980). The study covered the inner and middle shelf between $28^{\circ} 30$ and $32^{\circ} \mathrm{N}$ (Fig. 1), and was conducted between 21 October and 8 November, 1987. The basic finding of our observations to date has been the displacement of mid- and outer shelf zooplankton onto the inner shelf due to windstress.

\section{Methods}

Zooplankton were sampled on the transects off Cape Canaveral, St. Augustine and Brunswick (Fig. 1). Sampling occurred immediately after the CTD-cast, using its temperatureand salinity-profiles to guide our depth ranges of sampling. We divided at each station the water column from $2 \mathrm{~m}$ above the sea floor to $3 \mathrm{~m}$ below the surface into 3 depth ranges which were consecutively sampled with a Multiple-Net-System (MNS) using 73 micron mesh. The latter was chosen to collect quantitatively all copepodid stages and adults of calanoid and cyclopoid copepods. All samples were preserved in $2 \%$ formaldehyde.

\section{Results and Discussion}

First, we will present the horizontal and vertical distribution of temperature, salinity and five major zooplankton taxa from one transect off Brunswick, St. Augustine and Cape Canaveral, respectively. This will be followed by time-series data on the vertical distribution of three major zooplankton taxa off St. Augustine.

During most of the cruise, the winds were south-to-westward, which should have resulted in displacement of surface water towards shore. The temperature data (Fig. 2, from Chandler, et al., 1988) indicate well-mixed water columns from near-to offshore, with Gulf Stream influence 
offshore. Nearshore salinity levels (Fig. 3, from Chandler, et al., 1988) decrease from north to south, and low-salinity water extends farther offshore with increasing latitude.

The calanoid copepod Acartia tonsa is found in high abundance in estuarine and coastal waters of the Southeastern U.S.A. throughout the year (Bowman, 1971). Our data indicate that its abundance sharply decreases with distance from shore (Fig. 4), and is one order of magnitude lower near Cape Canaveral, as compared to the transects farther north. This copepod's abundance is usually not so much limited by salinity or temperature, but food abundance and predation (Paffenhofer and Stearns, 1988). This species was observed in high concentrations in coastal waters off Cape Canaveral during October/November 1953 in conjunction with water of very low salinity ( $<340 / 00$, Bowman, 1971). Displacement towards offshore of this and related species occurs when strong windstress displaces surface water offshore, as during the Spring Removal Experiment 1984, and as modeled by Wroblewski (1980).

The calanoid copepod Paracalanus occurred nearshore in similar abundances at all three latitudes, i.e., there were no alongshore differences (Fig. 5). This copepod was highly abundant on the middle shelf where the concentration was about 20 to $25 \%$ of that found nearshore. Contrary to Acartia tonsa, Paracalanus is hardly limited by food abundance, (Paffenhöfer and Stearns, 1988). Its horizontal gradients were quite pronounced, and hardly any observed vertically. This genus was also found in high concentrations on the inner and middle shelf during our Spring Removal Experiment 1984 off South Carolina, and during Summer 1976 in Onslow Bay throughout the water column (Paffenhöfer, 1980).

The calanoid copepod Temora turbinata is a major representative of subtropical upwellings (Paffenhofer, et al., 1987). During FLEX it showed nearshore horizontal and offshore vertical zonation with concentrations increasing with depth as found in our summer studies (Fig. 6). Whereas concentrations nearshore varied a lot among the three transects, the deeper mid-shelf concentrations were quite similar. The nearshore maximum off St. Augustine (stations 77 to 82) couid be the result of continuous onshore windstress displacing earlier upwelled mid-shelf water, containing reproducir.g $T$. turbinata, towards nearshore. 
The cyclopoid genus Oncaea occurs ubiquitously from polar to tropical seas, and from the open ocean to middle shelves and is usually not found nearshore. It is a poorly studied genus, which is partly explained by its small size and inadequate sampling. As with $T$. turbinata, Oncaea shows horizontal zonation nearshore, and vertical zonation offshore, with higher concentrations usually found with increasing depths (Fig. 7, Paffenhofer, et al., 1987). Oncaea attained a maximum on the inner shelf off St. Augustine, as was observed for $T$. turbinata. Both may have similar water mass origins as described earlier because both can be among the dominant upwelling zooplankton representatives on the Southeastern Shelf $\left(215,000\right.$ animals $\left.\cdot \mathrm{m}^{-3}\right)$.

The chaetoznath Sagitta enflata is neritic and is usually not found in nearshore waters. This was also observed during FLEX (Fig. 8). Throughout these observations, we found horizontal zonation, indicating pronounced vertical mixing, and maximum abundances on the middle shelf. During summer, $S$. enflata is usually more abundant in colder bottom waters than in the warmer upper mixed layer (e.g., Paffenhofer, 1980).

Last, we want to evaluate the abundances of Acartia tonsa, Paracalanus sp. and Temora turbinata over a period of 13 days off St. Augustine (Fig. 9). Stations of $A$. tonsa were $2.3 \mathrm{~km}$, of Paracalanus 7 to $9 \mathrm{~km}$, and of $T$. turbinata 13 to $16 \mathrm{~km}$ from shore. A. tonsa's abundance varied by one order of magnitude over time, decreasing after an early maximum. We will examine, day-byday, water displacement data (J.O. Blanton), check $A$. tonsa's size distribution for each date, and analyze chlorophyll distribution as we look for an explanation for this variability.

In contrast, Paracalanus varied only by about $50 \%$, and was about 40 times more abundant than $A$. tonsa near the end of our study. T. turbinata also showed little variability in overall abundance over time.

Throughout the study area and period, temperatures were favorable for growth and reproduction of all species investigated. A variable of unknown effects, however, is turbulence, which can influence the behavior of zooplankton (e.g., Costello, et al., 1988). There is no doubt that the pronounced windstress created turbulence in the entire water column, and most likely on scales of millimeters in the upper meters. Turbulence on such a small scale could theoretically 
enhance (encounter of prey) or reduce (by destroying the feeding current) feeding rates of zooplankton. Adding micro-( $\mu \mathrm{m}$ to $\mathrm{mm}$ ) to macro-oceanography ( $\mathrm{m}$ to $\mathrm{km}$ ) should greatly improve our understanding. Further intensive development of the "CritterCam" (in situ zooplankton counter and observer) should lead us to that. 


\section{LITERATURE CITED}

Bowman, T.E. 1971. The distribution of calanoid copepods off the Southeastern United States between Cape Hatteras and Southern Florida. Smithson. Contr. Zool. No. 96, 58 pp.

Chandler, W.S., L.P. Atkinson and C. Kim. 1988. FLEX-Hydrographic Data Report, OctoberNovember 1987, Old Dominion University Research Foundation, Tech. Rep. 88-5, 180 pp.

Costello, J.H., J.R. Strickler, A. Corker, G. Trager, C. Marrasé and R. Zeller, 1988. Behavioral response of a calanoid copepod, Centropages hamatus, to a turbulent environment. EOS 69:1145.

Paffenhofer, G.-A. 1980. Zooplankton distribution as related to summer hydrographic conditions in Onslow Bay, North Carolina. Bull. Mar. Sci. 30:819-832.

Paffenhöfer, G.-A. and D.E. Stearns. 1988. Why is Acartia tonsa (Copepoda: Calanoida) restricted to nearshore environments? Mar. Ecol. Progr. Ser. 42:33-38.

Paffenhofer, G.-A., B.K. Sherman and T.N. Lee. 1987. Summer upwelling on the southeastern continental shelf of the U.S.A. during 1981. Abundance, distribution and patch formation of zooplankton. Prog. Oceanog. 19:403-436.

Weber, A.H. and J. O. Blanton. 1980. Monthly mean wind fields for the South Atlantic Bight. J. Phys. Oceanog. 10:1256-1263.

Wroblewski, J.S. 1980. A simulation of the distribution of Acartia clausi: during Oregon upwelling, August 1973. J. Plankton Res. 2:43-68. 


\section{FIGURE LEGENDS}

Fig. 1 - FLEX: Study region (modified from Chandler, et al., 1988).

Fig. 2- Cross-shelf temperature distribution off Brunswick (top), St. Augustine (middle) and Cape Canaveral (bottom).

Fig. 3- Cross-shelf salinity distribution at the same latitudes as Fig. 2.

Fig. 4 Cross-shelf distribution of the calanoid copepod Acartia at the same latitudes as Fig. 2.

Fig. 5- Cross-shelf distribution of the calanoid copepod Paracalanus at the same latitudes as Fig. 2.

Fig. 6- Cross-shelf distribution of the calanoid Temora turbinata at the same latitudes as Fig. 2.

Fig. 7- Cross-shelf distribution of the cyclopoid copepod $O_{r}=a e a$ at the same latitudes as Fig. 2.

Fig. 8- Cross-shelf distribution of the chaetognath Sagitta enflata at the same latitudes as Fig. 2.

Fig. 9- Time-series of vertical distribution off St. Augustine from 24 October to 5 November 1987 of Acartia (2.3km offshore), Paracalanus (7 to 9km offshore), and $T$. turbinata (13 to $16 \mathrm{~km}$ offshore.) 
1.2 Manuscript Published During the Past Year

Paffenhöfer, G.-A. 1988. Feeding rates and behavior of zooplankton. Bull. Mar.

Sci. 43:430-445. 

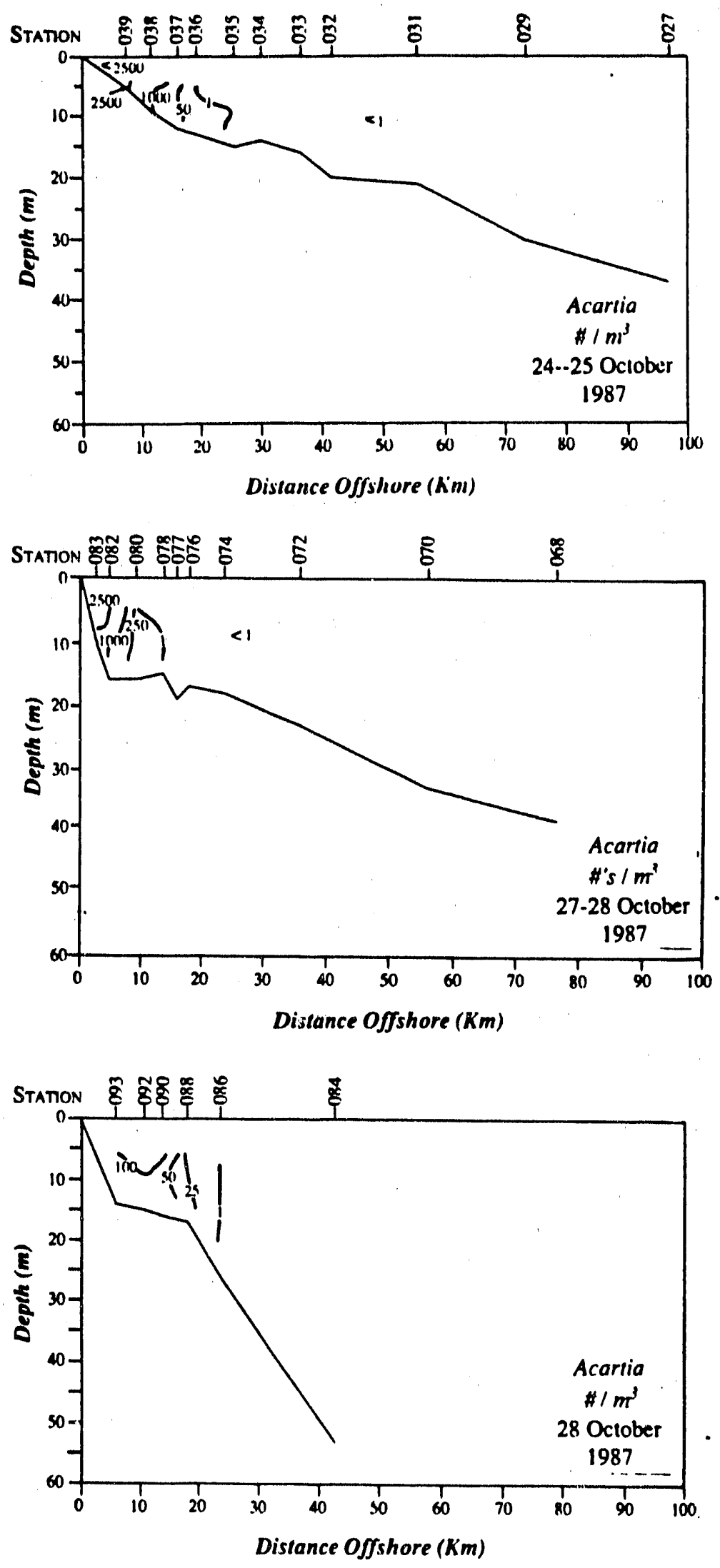

Fig. 4 - Cross-shelf distribution of the calanoid
copepod Acartia at the same latitudes as

Fig. 2. 

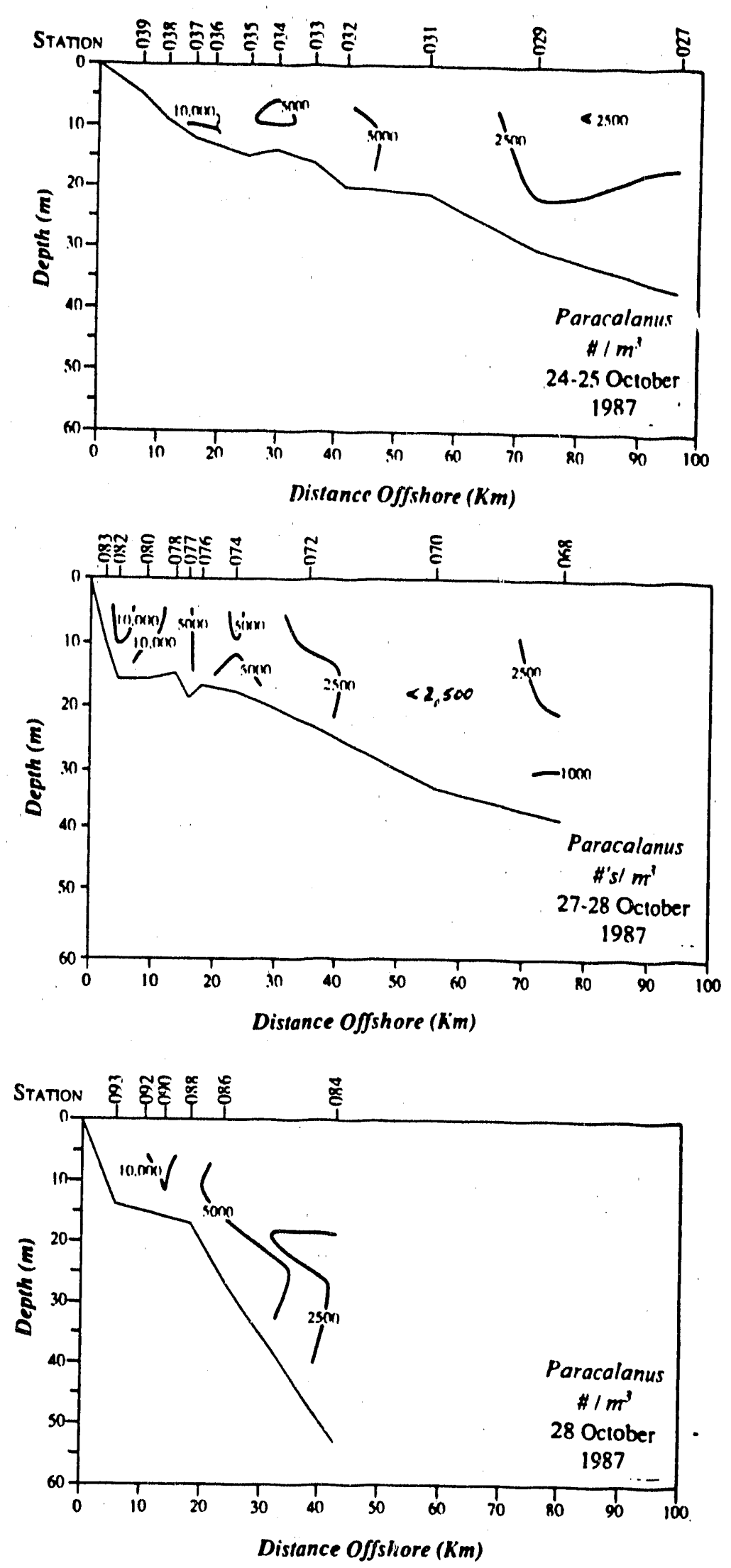

Fig. 5 - Cross-shelf distribution of the calanoid copepod Paracalanus at the same latitudes as Fig. 2. 

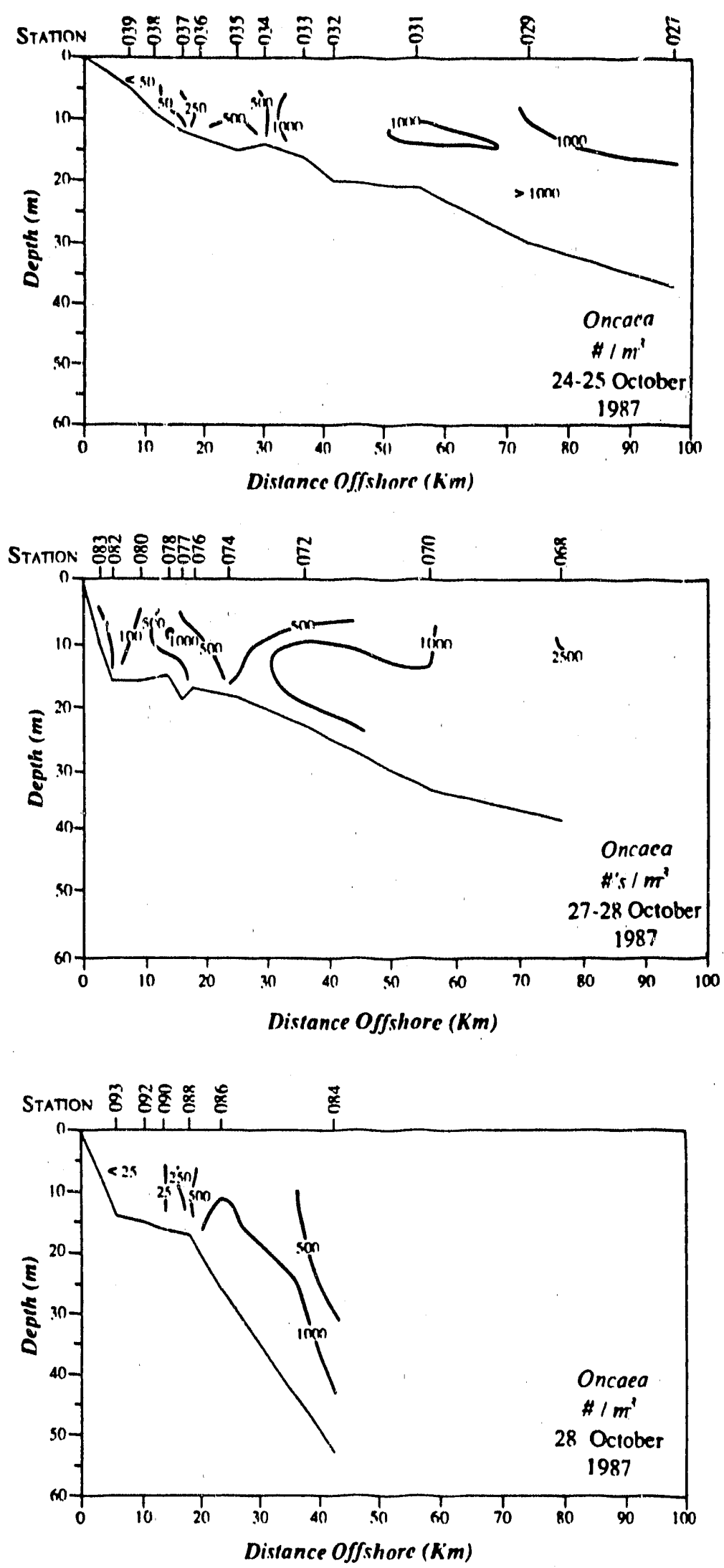

Fig. 7 - Cross-shelf distribution of the cyclopoid copepod Oncaea at the same latitudes as

Fig. 2. 

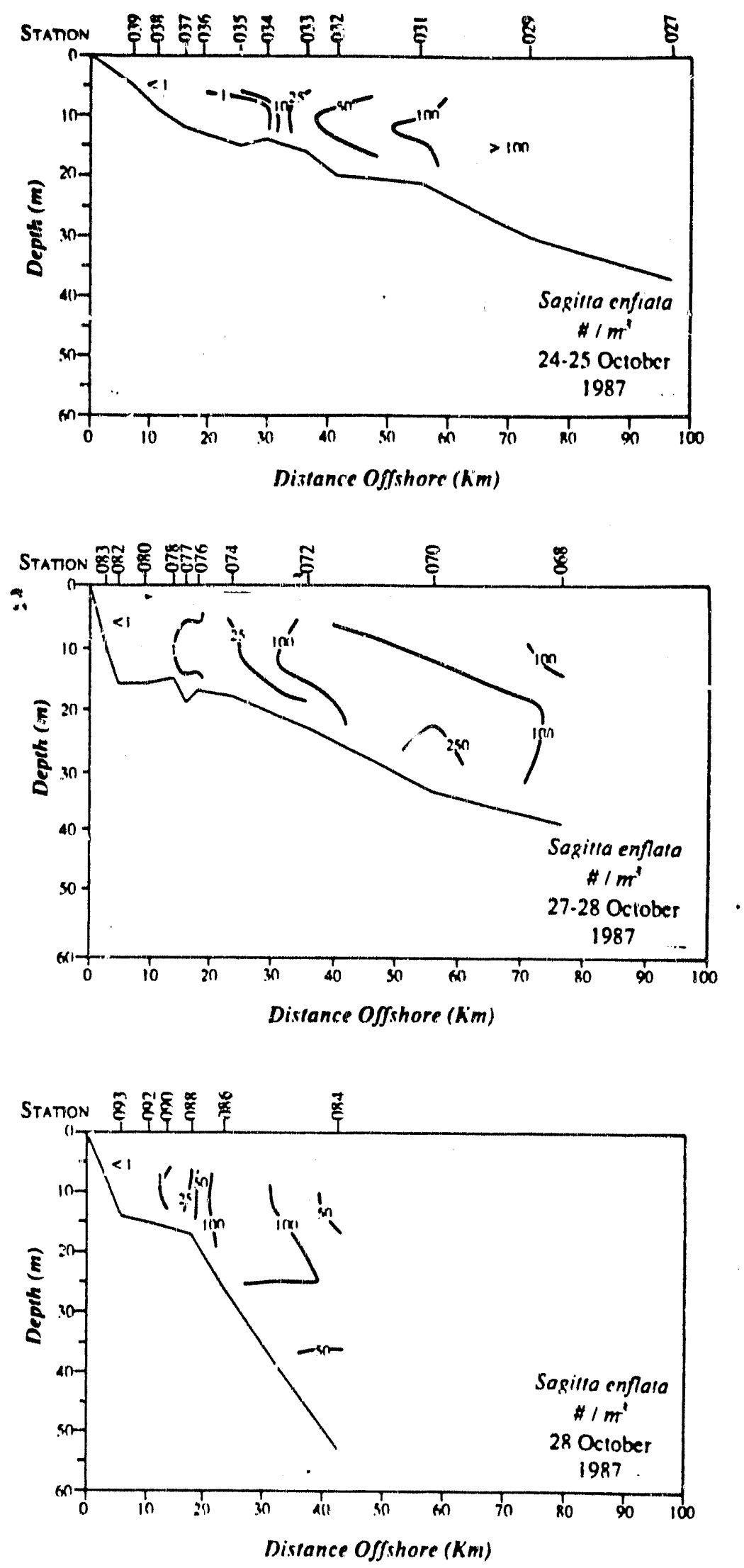

Fig. 8 - Cross-shelf distribution of the chaetognath Sagitta enflata at the same latitudes as Fig. 2. 

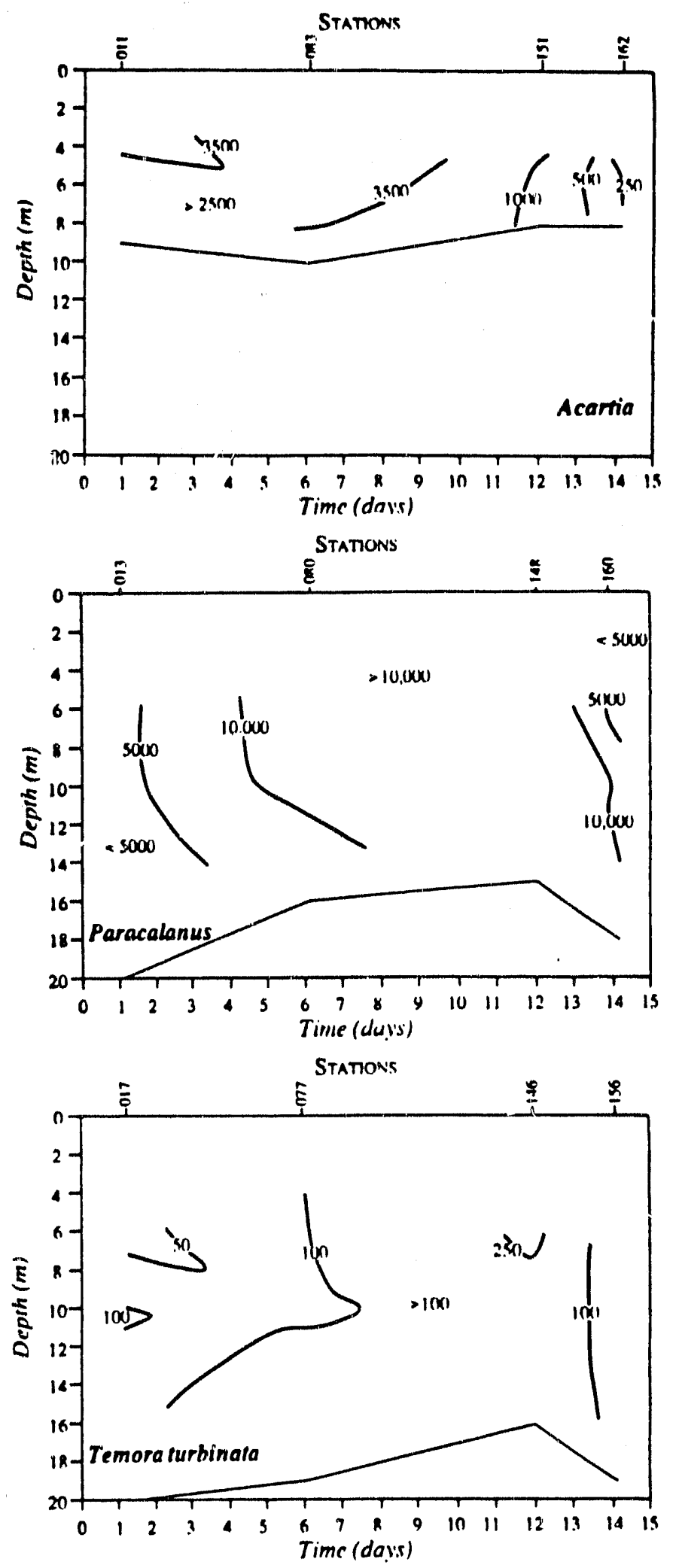

Fig. 9 - Time-series of vertical distribution off St. Augustine from 24 October to 5 November 1987 of Acartia (2.3km offshore), Paracalanus (7 to $9 \mathrm{~km}$ offshore), and T. turbinata (13 to $16 \mathrm{~km}$ offshore.) 

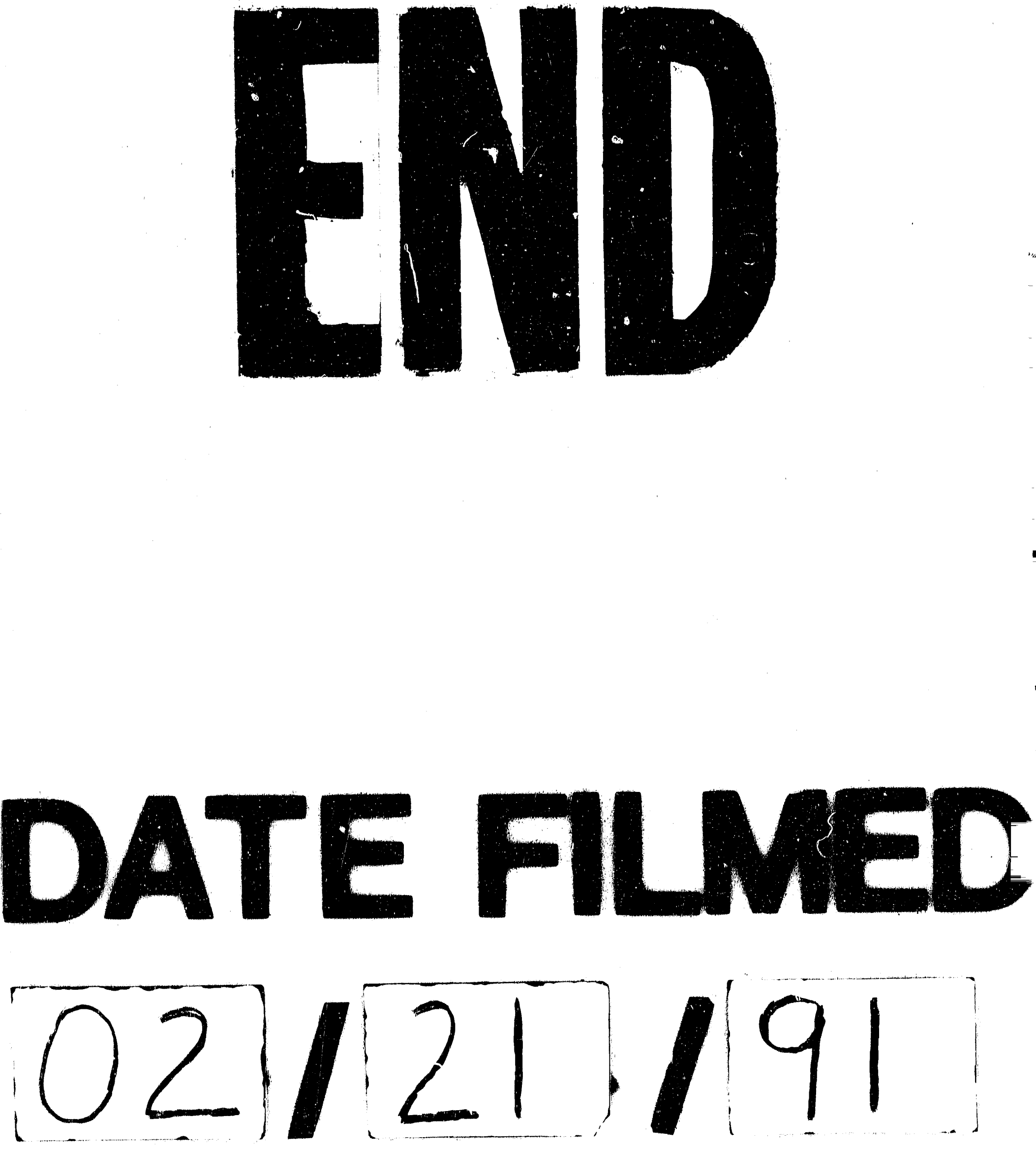
